\title{
Wirtualna Rzeczywistość (ANG. ViRTual Reality - VR) \\ JAKO SKUTECZNE NARZĘDZIE TERAPII FOBII SPOŁECZNEJ
}

\author{
Matgorzata KozŁowsKa \\ gosia.kozlowska13@wp.pl
}

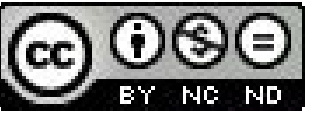

Wirtualna rzeczywistość rozbudza ludzką wyobraźnię. Powoduje, że przez chwilę można zapomnieć o codziennych problemach i zanurzyć się w fantazyjny świat. Osobom, które same potrafią kreować wirtualną przestrzeń, dostarcza ona niemalże nieskończonych możliwości tworzenia. Pozwala na symulowanie sytuacji trudnych do zrealizowania w realnym życiu, ułatwia komunikowanie się, może służyć za narzędzie ekspresji jej użytkowników1. I choć wirtualny świat kojarzy się zwykle z grami komputerowymi, niosącymi ze sobą często destruktywne wartości, niniejszy artykuł ukaże jeszcze jeden ze sposobów konstruktywnego zastosowania wirtualnego środowiska.

Jak zauważa Stanisław Juszczyk: „,Wirtualna rzeczywistość (ang. Virtual Reality - VR) oznacza wszystko to, co wygląda realistycznie, jest odczuwane realistycznie oraz działa lub zachowuje się realistycznie, aczkolwiek realistyczne w rzeczywistości nie jest"2 ${ }^{2}$. Słowa te doskonale obrazują właśnie tę cechę wirtualnego środowiska - łudzące podobieństwo do rzeczywistości, która zadecydowała o możliwości jego wykorzystania do leczenia realnych zaburzeń w nierealnym świecie.

Termin Virtual Reality (dalej w skrócie: VR) odnosi się do technologii, która umożliwia użytkownikom interakcje z komputerowo wygenerowanym światem dzięki wyspecjalizowanym narzędziom wizualno-słuchowo-kinestetycznym ${ }^{3}$. Idea zastosowania technologii VR do terapii różnych zaburzeń psychicznych po raz pierwszy pojawiła się na Uniwersytecie Clark Atlanta w 1992 r. ${ }^{4}$. Od tego czasu przeprowadzono wiele eksperymentów potwierdzających jej skuteczność, zwłaszcza w terapii różnorodnych fobii specyficznych. VR stosunkowo często znajduje zastosowanie, jako narzędzie diagnozy i terapii w krajach zachodnich (zwłaszcza w Anglii, Francji, USA), nie jest natomiast prawie wcale znana i wykorzystywana w Polsce, jako technologia umożliwiająca leczenie zaburzeń psychicznych. Stąd też celem niniejszego artykułu jest zaprezentowanie VR jako efektywnej techniki pracy terapeutycznej z osobami cierpiącymi na fobię społeczną.

Aby przedstawić istotę działania Terapii Wirtualną Rzeczywistością (dalej w skrócie: VRT), w odniesieniu do fobii społecznej, trzeba przyjrzeć się temu zaburzeniu, a także zapoznać się z podejściem poznawczo-behawioralnym, odgrywającym istotną rolę w jego terapii.

\section{CZYM JeST FOBIA SPOŁECZNA?}

Według DSM IV fobia społeczna to: „,silny, utrzymujący się strach przed jedną bądź większą liczbą sytuacji społecznych lub zadaniowych, w których osoba ma do czynienia z nieznanymi

1 P. Sitarski, Wstęna charakterystyka rzeczywistości wirtualnej, s. 12, http://www.scribd.com/doc/23369818/Piotr-Sitarski-Wst\%C4\%99pna-charakterystyka-rzeczywisto\%C5\%9Bci-wirtualnej, 24.04.2012.

2 S. Juszczyk, Komunikacja człowieka z mediami, Katowice-Warszawa 1998, s. 80.

3 M. North, S. M. North: Virtual Reality Therapy, http://edumatica.ing.ula.ve/Teleclases/Tecnomatica/Animatica/Teleclase/Formacion/Virtualia/Virtual\%20Reality\%20Therapy.pdf, 23.11.2011.

4 E. Klinger, Virtual Reality Exposure in the Treatment of Social Phobia, http://www.cybertherapy.info/cybertherapy/6_ Klinger.pdf, 23.04.2012.

5 DSM -IV (ang. Diagnostic and Statistical Manual of Mental Disorders) - czwarta edycja podręcznika diagnostycznego i statystycznego zaburzeń psychicznych opracowana przez Amerykańskie Towarzystwo Psychiatryczne. 
ludźmi lub jest poddawana ocenie (obserwacji ze strony innych)"'. Inna definicja ukazuje fobię społeczną jako: ,Znaczący i trwały lęk przed byciem ocenianym i osądzanym negatywnie przez innych, prowadzący do poczucia nieadekwatności, zakłopotania i upokorzenia" ${ }^{\prime \prime}$.

Rozpowszechnienie fobii społecznej waha się w granicach od 3\% do 13\% populacji. Objawy fobii społecznej pojawiają się zazwyczaj pomiędzy wiekiem dojrzewania (głównie od 15 r.ż.) do wczesnej dorosłości (w wieku 20 lat) w równym stopniu u kobiet, jak i u mężczyzn. Zaburzenie to może przyjąć formę konkretna, w postaci lęku przed określonymi rodzajami sytuacji społecznych, takimi jak np.: przemawianie przed publicznością lub granie na instrumentach muzycznych w trakcie koncertów; bądź formę uogólnioną, kiedy lęk towarzyszy jednostce w niemal każdej sytuacji ekspozycjir. Bardziej popularnym rodzajem fobii społecznej jest uogólniony lęk. Zarówno w jednej, jak i w drugiej formie, lęk ten pojawia się najczęściej w czasie różnego rodzaju wystąpień publicznych, $\mathrm{w}$ okolicznościach wymagających wykazania się asertywnością (obrona swoich interesów, poglądów, odmawianie), w momentach bycia obserwowanym przez innych czy w sytuacjach intymnych. Fobia społeczna może powodować znaczące pogorszenie funkcjonowania, tak w sferze osobistej, jak i zawodowej'.

Główną cechą fobii społecznej jest strach przed negatywną oceną ze strony publiczności ${ }^{10}$ (publiczność odnosi się tutaj nie tylko do wystąpień publicznych, ale do wszelkich sytuacji wiążących się z kontaktem z szerszym gronem osób, takich jak np.: jedzenie, picie, podpisywanie się, rozmowa z osobą nieznajomą lub z grupa $a^{11}$ ). Istotne jest także to, że osoby z fobią społeczną mają zazwyczaj niską samoocenę. W związku z tym są one przekonane o bezwartościowości każdego odbytego wystąienia i nastawione na poniesienie porażki w kolejnych. Temu przekonaniu towarzyszy zarazem mocne pragnienie wywołania pozytywnego wrażenia na odbiorcach i niepewność, co do własnych możliwości w tym zakresie ${ }^{12}$. Z tego też względu osoby z fobią społeczną traktują sytuacje społeczne jak niebezpieczeństwo; pewne sa, że będą zachowywać się nieporadnie, co może spotkać się z odrzuceniem otoczenia.

Skutkiem takich myśli, jak zauważyli David M. Clark i Adrian Wells - twórcy poznawczego modelu fobii społecznej, jest uruchomienie szeregu zmian fizjologicznych, poznawczych, afektywnych i behawioralnych. Zależność pomiędzy dysfunkcyjnymi przekonaniami a symptomami $w$ fobii społecznej obrazuje rys. $1^{13}$.

Na poziomie fizjologicznym, wzmaga się aktywność ośrodkowego układu nerwowego, co zwiększa takie reakcje organizmu, jak: pocenie się, drżenie rąk, czerwienienie, jąkanie, itp.

Do poznawczych aspektów fobii, w sytuacji lękowej, należy myślenie o negatywnej ocenie ze strony innych. W sferze afektu dochodzą wyobrażenia o niskiej samoocenie, co potęguje nieprzyjemne odczucia. Natomiast do behawioralnych wyznaczników zmian wywołanych myśleniem o sytuacji społecznej w kategorii niebezpieczeństwa należy stosowanie tzw. „zachowań zabezpieczających", tj. takich zachowań, które mają zapobiec ",katastrofie” towarzyskiej ${ }^{14}$. Zachowania zabezpieczające są jednak nieskuteczne na dłuższą metę, gdyż:

6 M. Trzcińska, Terapia fobii społecznej w ujęciu poznawczo-behawioralnym, „Psychiatria w Praktyce Ogólnolekarskiej” 2007, t. 7, nr 4, s. 177.

E. Klinger, S. Bouchard, dz. cyt., s. 76.

M. Trzcińska, dz. cyt., s. 177.

M. Leary, Lęk społeczny, Gdańsk 2001, s. 95.

A. Wells, Terapia poznawcza zaburzeń lękowych, Kraków 2010, s. 195.

Tamże, s. 195.

12 Tamże, s. 197.

13 Tamże.

14 A. Wells, dz. cyt., s. 198. 


\section{Rys. 1. Poznawczy model fobii społecznej według D. M. Clarke’a i A. Wellse’a}

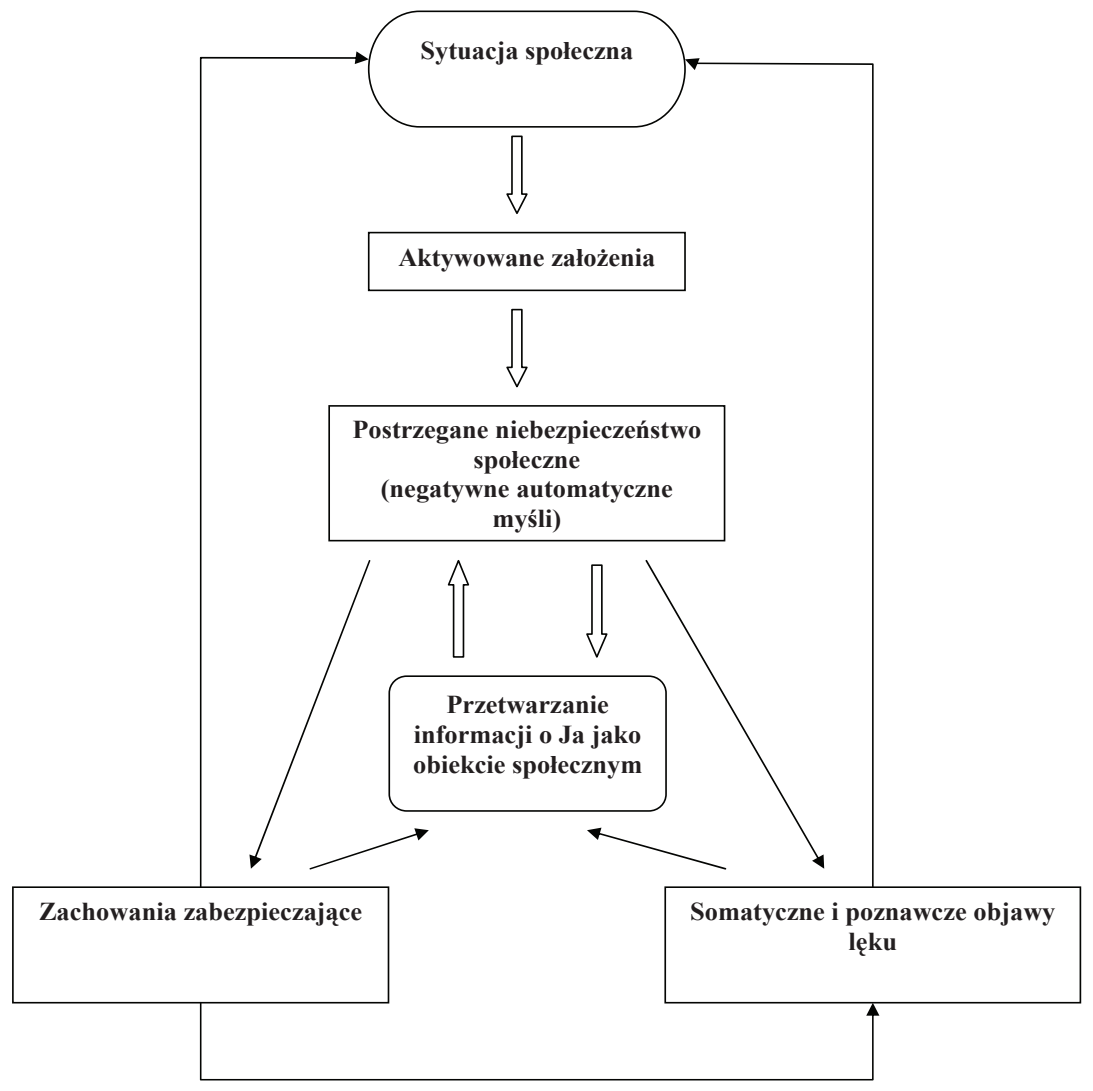

Źródło: A. Wells, dz. cyt., s. 197.

- niektóre z nich zwiększają objawy, przez co tylko utrudniają wystąpienia,

- powoduja, że osoba $z$ fobią może być postrzegana jako osoba zamknięta i nieprzyjaźnie (wręcz obronnie) nastawiona do grupy,

- uniknięcie »katastrofy« może być przez osobę z tego rodzaju fobią przypisywane właśnie stosowaniu zachowań zabezpieczających ${ }^{15}$.

Pojawienie się wymienionych objawów (razem tworzących „program lęku”) powoduje maksymalną koncentrację osoby na swej autoprezentacji w momencie wystąpienia. To z kolei ogranicza zdolność jednostki do zaabsorbowania sprawami otoczenia utrudniając wykonanie i obiektywną ocenę sytuacji. Osoba zaabsorbowana sobą może np. sądzić, że wszyscy bacznie ją obserwująi i są zdegustowani jej zachowaniem, bądź nią znudzeni. W momencie koncentracji na sobie, jednostka często przesuwa uwagę na przetwarzanie informacji z perspektywy zewnętrznego obserwatora, co przybiera formę wyobrażeń o swoim wyglądzie w oczach innych. Ponieważ osoba z fobią zauważa głównie odczucia ze swego ciała (które są negatywne), wyobrażenie to, $w$ jej perspektywie, jest także negatywne ${ }^{16}$.

\footnotetext{
15 Tamże, s. 198.

16 M. Leary, dz. cyt., s. 148.
} 
Fobia społeczna jest zaburzeniem, które wykracza poza same konkretne sytuacje społeczne, ciągnie się także poza nimi w postaci uporczywego rozmyślania o tych sytuacjach. Osoby z fobią często nie tylko przypominają sobie stale fragmenty poprzednich sytuacji, ale także planują w myślach przebieg kolejnej rozmowy i swoje zachowania w przyszłości. Sytuacje przypominane oczywiście są nacechowane negatywnie, gdyż odtwarzane są interoceptywne odczucia, na których koncentrowała swą uwagę osoba. W umysłach osób z fobią społeczną rozgrywa się nieustająca batalia odczuć i obrazów, w których jednostka taka zachowuje się w swoich oczach katastrofalnie, a przynajmniej nieodpowiednio do danej sytuacji17.

\section{Terapia Poznawczo-Behawioralna (Dalej w skrócie: TPB ) W LECZENIU FOBII SPOŁECZNEJ}

Zagadnienie leczenia fobii społecznej, wcześniej zaniedbywane, w ciagu ostatnich 15 lat stało się przedmiotem intensywnych badań. Wśród wielu dotychczasowych propozycii, często stosowaną i skuteczną metoda, okazało się podejście poznawczo-behawioralne, $\mathrm{w}$ którym fobia społeczna przedstawiona jest jako efekt dysfunkcyjnych przekonań jednostki, stawiających ją w jej własnych oczach w negatywnym świetle w sytuacjach społecznych. Przekonania takie powodują lęk antycypacyjny w odniesieniu do konfrontacji z odbiorem społecznym i w konsekwencji do postrzegania go jako sytuacji zagrażającej. Ważnym elementem terapii jest wykrycie przyczyn i procesu powstawania symptomów u konkretnej osoby, po to, by móc zminimalizować symptomy. Po wstępnym rozpoznaniu, terapia przebiega według ściśle określonego planu. Terapeuta dobiera odpowiednie techniki i metody do zwalczania objawów występujących u pacjenta, które są trenowane zarówno podczas sesji, jak i w postaci zadań do samodzielnego wykonania przez klienta między sesjami. Cała terapia skoncentrowana jest głównie na:

a) wykrywaniu i zwalczaniu dysfunkcyjnych przekonań - podejście poznawcze zakłada, iż objawy są skutkiem irracjonalnych przekonań, stąd też pierwszym krokiem w terapii jest ich identyfikacja i zastąpienie innymi, bardziej realistycznymi i często także bardziej optymistycznymi myślami ${ }^{18}$.

b) nabywaniu odpowiednich kompetencji społecznych - udowodniono, że ludzie dotknięci fobią społeczną często posługują się nieadaptacyjnymi zachowaniami w kontaktach społecznych, co może pogłębiać ich lęk przed sytuacjami ekspozycji. Dlatego też w terapii pacjenci uczą się określonych umiejętności społecznych, które następnie są ćwiczone metodą odgrywania ról, lub w myślach poprzez wyobrażenia ${ }^{19}$.

c) przezwyciężaniu skłonności do unikania sytuacji społecznych - terapia nie odniesie zamierzonych efektów, dopóki pacjent nie przełamie lęku przed wchodzeniem w interakcje ${ }^{20}$. Toteż stopniowe przyzwyczajanie pacjenta do trudnych, według niego, sytuacji odbywa się poprzez ekspozycję na coraz bardziej zagrażające bodźce i stopniową desensytyzację.

W czasie sesji, istotnym elementem jest ćwiczenie relaksacji, które obniża napięcie nerwowe i pozwala łagodzić symptomy ${ }^{21}$.

Badania nie wykazały, który z powyższych komponentów jest najbardziej skuteczny w redukowaniu fobii. Jednakże wydaje się, że ekspozycja na sytuacje lękotwórcze, zwłaszcza w po-

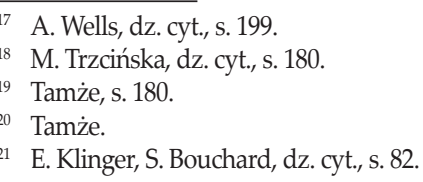


łączeniu z nauką radzenia sobie z takimi wyzwaniami, poprzez nabywanie konstruktywnych umiejętności, odgrywa fundamentalną rolę w zwalczaniu nadmiernego lęku społecznego.

\section{ZASTOSOWANIE VR W TERAPII FOBII SPOŁECZNEJ}

W tradycyjnej terapii poznawczo-behawioralnej zasadniczą rolę odgrywa stopniowa ekspozycja na bodźce wywołujące objawy fobii, która polega na odtwarzaniu przez pacjenta w wyobraźni określonych trudnych sytuacji. Nie zawsze jednak ten rodzaj ekspozycji okazuje się skuteczny, głównie ze względu na trudności wielu pacjentów w wyobrażaniu sobie awersyjnych sytuacji. Terapia Wirtualną Rzeczywistością jest nowym sposobem leczenia umożliwiającym klientom konfrontację z trudnymi dla nich sytuacjami i radzenie sobie z ich irracjonalnymi zachowaniami przy użyciu technologii VR²2. Dzięki VR możliwe jest uniknięcie tych przeszkód i prowadzenie ekspozycji w relatywnie bezpiecznym środowisku, którego poszczególne elementy mogą być w pełni kontrolowane przez terapeutę, w zależności od potrzeb pacjenta. Ponadto, VR pozwala na izolowanie określonych parametrów determinujących dysfunkcjonalne reakcje oraz umożliwia kreowanie środowisk trudnych do zaaranżowania w rzeczywistym świecie podczas terapii. Ćwiczenie umiejętności nabytych w czasie terapii w wirtualnym środowisku można traktować zatem jako pierwszy krok przed ich zastosowaniem w rzeczywistych interakcjach. Technika VR nie ogranicza się jedynie do obserwowania zdarzeń na komputerze, ale pozwala aktywnie uczestniczyć w trójwymiarowym wirtualnym świecie. Wrażenie „realności” zapewniają:

- tzw. output tools - narzędzia wizualne, dotykowe i słuchowe, które umożliwiają „zanurzenie" w wirtualnym świecie,

- tzw. input tools - rękawice, czujniki, myszka rejestrujące ruch i położenie użytkownika,

- generator wirtualnego środowiska,

- baza konstrukcji i wirtualnych obiektów do budowania, utrzymywania detali oraz realistycznych modeli ${ }^{23}$.

Biorąc pod uwagę sposób interakcji z VR, można wyróżnić co najmniej cztery rodzaje środowisk wirtualnych:

- Pełno-zanurzeniowe VR [tłum. wł.] - umożliwiające uczestnikowi odczuwanie wirtualnego środowiska wieloma zmysłami, dzięki zastosowaniu hełmu wideo i systemu czujników zapewniających koordynację między ruchami uczestnika a zmianami środowiska,

- Immersive VR - VR generowane przez pulpit [tłum. wł.] w postaci stereoskopowych wizualizacji, tzw. Desktop VR,

- VR emitowane na ścianach specjalnego pomieszczenia [tłum. wł.], umożliwiające terapię kilku osób jednocześnie, tzw. Cave-based VR,

- Rzeczywistość poszerzona [tłum. wł.], w której wirtualne obiekty są dopełnieniem środowiska realnego, tzw. Augmented VR ${ }^{24}$.

\section{TERAPIA VR}

Terapia przy pomocy wirtualnej rzeczywistości odbywa się zgodnie z wszystkimi głównymi założeniami charakterystycznymi dla podejścia poznawczo-behawioralnego, z tą jednak różnica, że ekspozycja w wyobraźni jest tu zastąpiona przez ekspozycję na sytuacje wykreowane w wirtualnym świecie. Aby zobrazować przebieg leczenia z zastosowaniem wirtualnego śro-

22 M. North, S. M. North, dz. cyt.

23 G. Riva, A. Gaggioli, Virtual Clinical Therapy, „Digital Human Modeling” 2008, t. 4650, s. 91.

24 Tamże, s. 91. 
dowiska autorka przytoczy w skrócie plan terapii VR opracowany przez dr Evelyne Klinger i współpracowników z Państwowej Wyższej Szkoły Inżynierii w Caen²

Ogólne założenia organizacyjne terapii - Przed przystąpieniem do ekspozycji należy poddać pacjenta serii testów służących do wstępnego oszacowania poziomu nasilenia zaburzenia. Testy przeprowadza się także tuż po zakończeniu terapii oraz po upływie sześciu miesięcy od czasu ostatniej sesji w celu sprawdzenia trwałości rezultatów. Terapia zakłada odbycie dwunastu sesji indywidualnych prowadzonych przez terapeutę poznawczo-behawioralnego $\mathrm{w}$ okresie od trzech do czterech miesięcy. Czas każdej sesji przewidziano na 45 minut, z czego mniej niż 20 minut jest zarezerwowane na ekspozycję w Immersive VR. Po zakończeniu każdej części terapii, prowadzący omawia wraz z pacjentem zadania do samodzielnego wykonania przez pacjenta przed kolejnym spotkaniem.

Struktura sesji VRT - Podczas pierwszego spotkania z pacjentem terapeuta zaznajamia go z przebiegiem terapii oraz z obsługą narzędzi wirtualnego środowiska, do czego służy zaprojektowana do tego celu symulacja przestrzeni „neutralnej”. Celem jest nauczenie klienta posługiwania się narzędziem, dlatego też znajdują się w nim same przedmioty a nie postacie ludzkie. Osiem następnych sesji stanowi rdzeń terapii, gdyż w czasie ich trwania pacjent poddawany jest ekspozycji $\mathrm{w}$ wirtualnym środowisku na sytuacje intymne, wystąpienia publiczne, związane z wrogością innych, wymagające od niego asertywności. Celem treningu odbywanego w pierwszym środowisku jest nauka asertywności: obrony własnych interesów, poglądów, umiejętności odmawiania. Drugie środowisko wiąże się z życiem prywatnym. Klient uczy się jak nawiązywać kontakty z przyjaciółmi, czy prowadzić krótką konwersację. W trzecim środowisku klient trenuje opanowywanie lęku w sytuacji bycia obserwowanym, oraz w jaki sposób zachowywać się, gdy wszyscy wokół nastawieni są negatywnie. W czwartym środowisku klient uczy się jak występować w publicznych przemówieniach zarówno przy neutralnej, aprobującej, jak i znudzonej publiczności ${ }^{26}$.

Ekspozycja w wirtualnym środowisku zawsze musi się odbywać pod stałym nadzorem terapeuty szkoły poznawczo-behawioralnej, który decyduje o powtórzeniu, przedłużeniu bądź zatrzymaniu terapii, w zależności od zachowania pacjenta. Pierwsza konfrontacja, z każdego rodzaju sytuacją zagrażająca, służy wstępnej diagnozie stopnia radzenia sobie przez pacjenta; w czasie następnych trzech ekspozycji (razem cztery próby na jeden rodzaj środowiska) pacjent stara się wprowadzać konstruktywne przekonania i zachowania proponowane przez terapeutę.

Całość dopełniają polecenia realizowane przez pacjenta między sesjami w rzeczywistym świecie, które są komplementarne do występujących w czasie sesji terapeutycznych. Zadania te, zalecane do wykonania po każdej sesji, mają na celu głównie rozwijanie adaptacyjnych zachowań w rzeczywistym świecie, takich jak: zachowania asertywne, ograniczanie zachowań unikowych oraz pracę poznawczą poprzez: wychwytywanie dysfunkcyjnych przekonań i ich modyfikację.

W czasie dziesiątej i jedenastej sesji pacjent wybiera ekspozycję sprawiającą mu najwięcej problemów i raz jeszcze powtarza ją w celu utrwalenia konstruktywnych zachowań. Na dwunastej sesji następuje podsumowanie postępów klienta i udzielenie mu przez terapeutę ostatnich wskazówek ${ }^{27}$.

Terapia wirtualną rzeczywistością prowadzona jest zgodnie z trzema głównymi regułami:

1. Diagnozowanie - W czasie ekspozycji, terapeuta bada reakcje pacjenta na środowisko poprzez pytania dotyczące:

- $\quad$ sfery poznawczej:,JJakie myśli przychodzą Ci do głowy?” - pomagające ocenićsubiektywny poziom „zagrożenia” odczuwanego przez pacjenta oraz jego zasoby radzenia sobie,

${ }_{25}$ E. Klinger, S. Bouchard, dz. cyt., s. 26.

26 Tamże, s. 80.

27 Tamże, s. 82. 
- sfery emocjonalnej: „,Co czujesz?" - potrzebne do oszacowania stopnia natężenia emocji,

- sfery behawioralnej: „Co robisz?” - mogące pomóc w identyfikowaniu zachowań unikowych, pasywnych lub agresywnych.

2. Spontaniczność - Podczas ekspozycji terapeuta pozwala pacjentowi zachowywać się spontanicznie, w sposób jak najbardziej zbliżony do stylu reagowania w realnych sytuacjach, by móc poprawić nieadaptacyjne wzorce i utrwalać konstruktywne.

3. Udzielanie instrukcji - Podczas sesji terapeuta instruuje pacjenta o zachowaniach adaptacyjnych do danej sytuacji w sferze behawioralnej (poprzez konfrontację z sytuacja, asertywność), poznawczej i emocjonalnejej.

Należy oczywiście pamiętać, iż mimo dużej roli, jaką w tego rodzaju terapii odgrywa ekspozycja na wirtualne środowisko, niezbędna i niezaprzeczalnie najważniejsza jest funkcja terapeuty poznawczo-behawioralnego, który przewodzi pacjentowi w czasie ekspozycji, otrzymuje informacje zwrotne od klienta oraz zleca mu określone zadania do wykonania między sesjami.

\section{EFEKTYWNOŚć VRT}

Badania prowadzone przez E. Klinger ì współpracowników wykazały, iż VRT wykazuje zbliżoną efektywność jak tradycyjna TBP zwłaszcza w sytuacjach intymnych, bycia ocenianym przez innych czy wystąień publicznych ${ }^{29}$. Inne badania wskazują na podobną efektywność VRT w porównaniu z TPB w terapii lęku przed publicznymi wystąpieniami. Ponadto, M. North i współpracownicy, bazując na danych z subiektywnych wypowiedzi uczestników VRT, sformułowali twierdzenia odnoszące się do właściwości relacji między użytkownikiem a VR:

- poczucie tzw. presence czyli odczuwania wirtualnej rzeczywistości jako realnej [tłum. wł. $]^{30}$ towarzyszy uczestnikom $w$ VR nawet, gdy jej elementy nie są dokładnym odzwierciedleniem realiów świata zewnętrznego,

- $\quad$ sytuacje w VR wywołują analogiczne reakcje i emocje jak sytuacje w środowisku rzeczywistym ${ }^{31}$.

Odczuwana realność wirtualnego środowiska powoduje, iż dokonane w nim zmiany mogą wpływać na modyfikację percepcji świata realnego i zachowania w rzeczywistym środowisku.

Należy jeszcze wspomnieć, iż VRT znajduje swoje zastosowanie nie tylko w terapii fobii społecznej czy innych postaci fobii specyficznych, takich jak np.: lęk wysokości, lęk przed wystąieniami publicznymi, lęk przed lataniem, itp. VRT z powodzeniem nadaje się także do leczenia zaburzeń odżywiania ( bulimia i anoreksja), syndromu PTSD, zaburzeń seksualnych i radzenia sobie z bólem² ${ }^{32}$.

\section{UJEMNE STRONY VRT}

Mimo opisanych powyżej zalet wirtualnego środowiska w terapii fobii społecznej, w praktyce pojawiają się także jego ujemne strony, takie jak np.:

- brak odpowiednio wystandaryzowanego sprzętu komputerowego i jego oprogramowania oraz ograniczone możliwości kreowania środowiska wirtualnego do specyficznych potrzeb praktyki klinicznej,

28 Tamże.

29 Tamże, s. 84.

30 B. G Witmer, M. J. Singer, Measuring Presence in Virtual Environments: A Presence Questionnaire, http://www.mendeley.com/research/measuring-prescence-in-virtual-environments-a-presence-questionnaire/, 24.04.2012.

31 E. Klinger, Virtual Reality Exposure in the Treatment of Social Phobia, http://www.cybertherapy.info/cybertherapy/6_ Klinger.pdf, 23.04.2012.

32 K. Glantz, M. Bacchetta i in., Opportunities and challenges, "Presence, Teleoperators and Virtual Environments” 1997, nr 6, s. 87-105. 
- wysokie koszty projektowania i testowania aplikacji VR,

- wysokie koszty eksploatacji narzędzi VR,

- korzystanie z VR nie jest zalecane dla osób po zawałach serca, z depresja, może także powodować bóle głowy ${ }^{33}$.

\section{Podsumowanie}

Fobia społeczna jest jednym z najbardziej rozpowszechnionych zaburzeń psychicznych. Terapia tego zjawiska opiera się przede wszystkim na ekspozycji na sytuacje stresowe, która w tradycyjnych ujęciach odbywa się głównie w wyobraźni pacjenta. VR może być doskonała alternatywą dla standardowych technik, dającą możliwość przeprowadzania ekspozycji w bardzo zróżnicowanych i relatywnie bezpiecznych środowiskach. VR jest narzędziem znacznie ułatwiającym pacjentom ćwiczenie konstruktywnych zachowań. Poprzez zastosowanie nowoczesnej technologii, możliwe stało się kreowanie środowiska terapeutycznego, które daje się niemal całkowicie kontrolować i dowolnie dostosowywać do bieżących potrzeb terapii. Ponadto, jak wskazują badania, VR nadaje się także do leczenia innych zaburzeń, takich jak: zaburzenie odżywiania, zaburzenia seksualne czy różnego rodzaju fobie specyficzne. Mimo wymienionych $\mathrm{w}$ niniejszym artykule zalet, $\mathrm{w}$ Polsce do tej pory nie istnieje powszechnie stosowane wirtualne środowisko do celów terapii. Można by spekulować, co do przyczyn takiego stany rzeczy. Autorka artykułu sądzi, iż głównym źródłem braku wykorzystywania wirtualnej przestrzeni w terapii jest nie tylko niedostateczna ilość funduszy, ale przede wszystkim brak wiedzy, co do możliwości, jakie stwarza tego rodzaju narzędzie. Biorąc bowiem pod uwagę fakt, że komputerowo wygenerowane środowisko jest atrakcyjne zwłaszcza dla młodych ludzi, można by się spodziewać nie tylko wzrostu zainteresowania samym sposobem terapii, ale i zwiększonej liczby osób, którym udało się pomóc w przezwyciężeniu lęku przed sytuacjami społecznymi.

Ponadto, rozpatrując zjawisko presence, należy zastanowić się nad oddziaływaniem w ogóle wirtualnego środowiska na ludzkie życie. Efekt przeniesienia zmian funkcjonowania człowieka zachodzących w wirtualnej przestrzeni do rzeczywistości, może występować przecież nie tylko w wirtualnym środowisku stworzonym specjalnie do celów terapii, ale i w każdej innej cyberprzestrzeni. Siła jego oddziaływania jest tym większa, im większe jest zaangażowanie odbiorcy W wirtualny świat. Jednakże to, w jaki sposób wirtualne środowisko będzie oddziaływać na codzienne funkcjonowanie zależy $w$ dużej mierze od wiedzy, jaką posiada jego użytkownik na temat istnienia tego wpływu i zgodnego z nia, świadomego eksploatowania wirtualnej przestrzeni.

Przedstawiając sposób terapii przy pomocy wirtualnej rzeczywistości, autorka żywi nadzieję na rozpowszechnienie zainteresowania tą formą terapii i konstruowanie nowych środowisk wirtualnych, ułatwiających leczenie wyżej wymienionych zaburzeń.

\section{Bibliografia}

Anderson P. L., Zimand E. i in., Cognitive Behavioral therapy for public-speaking anxiety using virtual reality for exposure, „Depression and Anxiety" 2005, nr 22.

Glantz K., Bacchetta M. i in., Opportunities and challenges, „Presence, Teleoperators and Virtual Environments” 1997, nr 6. Harris S. R., Kemmerling R. L., North M. M., Brief Virtual Therapy for Public Speaking Anxiety, „, CyberPsychology\&Behavior" 2002, nr 6.

Juszczyk S., Komunikacja człowieka z mediami, Katowice-Warszawa 1998.

Klinger E., Bouchard S., Virtual Reality Therapy Versus Cognitive Behavioral Therapy for Social Phobia: Preliminary Controlled Study, ,"CyberPsychology \& Behavior" 2005, nr 1.

33 G. Riva, A. Gaggioli, dz. cyt., s. 102. 
Leary M., Lęk spoteczny, Gdańsk 2001.

Riva G., Gaggioli A., Virtual Clinical Therapy, „,Digital Human Modeling” 2008, t. 4650.

Slater M., Pertaub D. P., Barker Ch. i in., Rapid Communication. An Experimental study on Fear of Public Speaking Using a Virtual Environment, "CyberPsychology\&Behavior" 2006, nr 5.

Trzcińska M., Terapia fobii społecznej w ujęciu poznawczo-behawioralnym, „, Psychiatria w Praktyce Ogólnolekarskiej” 2007, t. $7, \mathrm{nr} 4$.

Wells A., Terapia poznawcza zaburzeń lękowych, Kraków 2010.

\section{Netografia}

Klinger E., Virtual Reality Exposure in the Treatment of Social Phobia,

http://www.cybertherapy.info/cybertherapy/6_Klinger.pdf, 23.04.2012.

North M., North S. M., Virtual Reality Therapy,

http://edumatica.ing.ula.ve/Teleclases/Tecnomatica/Animatica/Teleclase/Formacion/Virtualia/Virtual\%20Reality\%20 Therapy.pdf, 23.11.2011.

Sitarski P., Wstępna charakterystyka rzeczywistości wirtualnej,

http://www.scribd.com/doc/23369818/Piotr-Sitarski-Wst\%C4\%99pna-charakterystyka-rzeczywisto\%C5\%9Bciwirtualnej, 24.04.2012.

Witmer B. G., Singer M. J., Measuring Presence in Virtual Environments: A Presence Questionnaire,

http://www.mendeley.com/research/measuring-prescence-in-virtual-environments-a-presence-questionnaire/, 24.04.2012.

\section{STRESZCZENIE}

Fobia społeczna jest jednym $\mathrm{z}$ najbardziej rozpowszechnionych zaburzeń obejmującym swym zasięgiem do 13 \% populacji. Virtual Reality - jest dobrze znanym i stosunkowo często stosowanym narzędziem diagnozy i terapii fobii w krajach zachodnich (zwłaszcza w Anglii, Francji, USA), natomiast w Polsce jest to technologia bardzo mało wykorzystywana do tego celu. Stąd też w artykule przedstawiona została Terapia Wirtualną Rzeczywistością jako forma leczenia, w której ekspozycja zachodząca w wirtualnej rzeczywistości przynosi wiele korzyści. Artykuł prezentuje możliwości jakie stwarza VR, jego rodzaje oraz zastosowanie. Aby zobrazować działanie VRT autorka przytacza w tekście przykład opracowany przez E. Klinger i jej współpracowników.

Słowa kluczowe: rzeczywistość wirtualna, terapia wirtualną rzeczywistościa, fobia społeczna, fobie specyficzne, terapia poznawczo-behawioralna.

\section{Virtual Reality as an Effective Tool for Treating Social Phobia}

\section{Summary}

The Social Phobia is one of the most common disorder ranging about 13\% of population. Virtual Reality is well known and relatively often used tool of assessment and treatment of phobia in the western countries (especially in UK, France and USA), but not in Poland. Hence, the main objective of the article is to present Virtual Reality Therapy as an efficient sort of treatment, which brings out many advantages. The author shows many possibilities connected with using VR, types of VR and it's application. The VRT by Klinger and her colleagues is instanced to show its operation.

Key words: Virtual Reality, Virtual Reality Therapy, Social Phobia Disorder, Specific Phobias, Cognitive-Behavioral Therapy. 